\title{
A note on the 1997 survey of the translocated Ultramarine Lory Vini ultramarina population on Fatu Hiva, Marquesas Islands, French Polynesia
}

\author{
A. LIEBERMAN, C. KUEHLER, A. VARNEY, P. UNITT, R. M. SULPICE, J. \\ AZUA and B. TEHEVINI
}

In 1991 a survey was conducted in the Marquesas Islands to determine the current range and population size of the Ultramarine Lory Vini ultramarina. A total of 313 birds were counted, restricted to one island, Ua Huka. A translocation program was initiated to capture and relocate birds to a less disturbed island. Fatu Hiva, an island within the historical range of the species, was chosen to establish a second population. This island still supports suitable habitat and does not have a resident population of Rattus rattus, which may have contributed to the decline of the species on Nuka Hiva and Ua Pou. Increased agriculture, grazing herbivores, bees, and banana plant disease may have also contributed to the decline.

Twenty-nine birds were captured on Ua Huka and relocated to Fatu Hiva on 28 August 1992 (seven birds), 24 November 1993 (seven birds) and 23 October 1994 ( 15 birds). Monitoring of the birds after release was accomplished by the Service de L'Economie Rurale (SER) (Kuehler et al., 1997).

During the period 19 January-27 January 1997, three observers surveyed Fatu Hiva to determine the status of the translocated population of Ultramarine Lories, all field efforts being focused in habitats likely to support the species. The village of Omoa, Omoa Valley, Hanaveve Valley, Puipuauwihi Valley, Yolande Valley, Tetana Valley, Ouia Valley and the mountain range between the Ouia and Hanaveve valley were surveyed. Fifty-one Ultramarine Lories were counted including ten birds in subadult plumage; one fledgling (completely sooty black) was being fed by a parent. We conclude that translocated Ultramarine Lories from Ua Huka are surviving and reproducing on Fatu Hiva.

\section{Acknowledgments}

The authors would like to acknowledge the support of the people of French Polynesia and France who made this program possible: Jean-Claude Thibault, Jean-Michel Sionneau, Philippe Raust, Philippe Siu, Claude Monnet, Michel Guerin, Loana Sanford, Leon Lichtle, Benjamin Teikihuavanaka, Didier Lequeux, Petrano Rogatien, Yolande Vernaudon, Kamia Kehu, the Rohi family, Norma Ropati, Yolande Taputu, Professor Tia and the Omoa Elementary School. A special thanks to Mere Roberts for her unpublished data on rats in French Polynesia. The Polynesia Lory Project was funded by the Zoological Society of San 
Diego and the Delegation de L'Environnement, French Polynesia. Biological staff support was donated by the Peregrine Fund, Inc. and the San Diego Natural History Museum.

\section{References}

Kuehler, C,, Lieberman, A., Varney, A., Unitt, P., Sulpice, R.M., Azua, J. and Tehevini, B. (1997) Translocation of Ultramarine Lories Vini ultramarina in the Marquesas Islands: Ua Huka to Fatu Hiva. Bird Conserv. Internat. 7: 69-79.

\section{A. LIEBERMAN and C. KUEHLER}

The Peregrine Fund, Inc. P.O. Box 39, Volcano, Hawaii 96785, U.S.A.

\section{A. VARNEY}

Delegation de l'Environnement, B.P. 590, Papeete, Tahiti, French Polynesia.

P. UNITT

San Diego Natural History Museum, P.O. Box 1390, San Diego, California 92112, U.S.A.

R.M. SULPICE

Service de l'Economie Rurale, Hokatu, Ua Huka, Marquesas Islands, French Polynesia.

J. AZUA

Zoological Society of San Diego, P.O. Box 551, San Diego, California 92112, U.S.A.

B. TEHEVINI

Service de l'Economie Rurale, Omoa, Fatu Hiva, Marquesas Islands, French Polynesia. 